\title{
Pacing Problem
}

National Cancer Institute

\section{Source}

National Cancer Institute. Pacing Problem. NCI Thesaurus. Code C63169.

Problem associated with the inability of the device to generate a therapeutic simulated heart beat via electrical impulses. 